University of Nebraska - Lincoln

DigitalCommons@University of Nebraska - Lincoln

March 1995

\title{
Addition of Cellulolytic Clostridia to the Bovine Rumen and Pig Intestinal Tract
}

\author{
Vincent $\mathrm{H}$. Varel \\ Roman L. Hruska U.S. Meat Animal Research Center, USDA Agricultural Research Service, Clay Center, \\ Nebraska \\ J.T. Yen \\ Roman L. Hruska U.S. Meat Animal Research Center, USDA Agricultural Research Service, Clay Center, \\ Nebraska \\ Kelly K. Kreikmeier \\ Roman L. Hruska U.S. Meat Animal Research Center, USDA Agricultural Research Service, Clay Center, \\ Nebraska
}

Follow this and additional works at: https://digitalcommons.unl.edu/usdaarsfacpub

Part of the Agricultural Science Commons

Varel, Vincent H.; Yen, J.T.; and Kreikmeier, Kelly K., "Addition of Cellulolytic Clostridia to the Bovine Rumen and Pig Intestinal Tract" (1995). Publications from USDA-ARS / UNL Faculty. 62.

https://digitalcommons.unl.edu/usdaarsfacpub/62

This Article is brought to you for free and open access by the U.S. Department of Agriculture: Agricultural Research Service, Lincoln, Nebraska at DigitalCommons@University of Nebraska - Lincoln. It has been accepted for inclusion in Publications from USDA-ARS / UNL Faculty by an authorized administrator of DigitalCommons@University of Nebraska - Lincoln. 


\title{
Addition of Cellulolytic Clostridia to the Bovine Rumen and Pig Intestinal Tract
}

\author{
VINCENT H. VAREL, * J. T. YEN, AND KELLY K. KREIKEMEIER $\dagger$ \\ Roman L. Hruska U.S. Meat Animal Research Center, USDA Agricultural Research Service,
} Clay Center, Nebraska 68933

Received 15 September 1994/Accepted 20 December 1994

\begin{abstract}
Studies were conducted to determine whether intestinal cellulolytic bacteria could be introduced into the bovine rumen or pig large intestine. In the first study, the ruminal fluid of three cows was evacuated and replaced with 20 liters of buffer and 6 liters of the ruminal or swine cellulolytic organism Clostridium longisporum or Clostridium herbivorans, respectively. The introduced organisms were the predominant cellulolytic bacterium in the fluid $\left(>10^{7}\right.$ cells $\left.\mathrm{ml}^{-1}\right)$ at $0 \mathrm{~h}$. C. longisporum was still the predominant cellulolytic organism after $5 \mathrm{~h}$, at $0.55 \times 10^{7}$ cells $\mathrm{ml}^{-1}$; however, after $24 \mathrm{~h}$ the count of $C$. longisporum decreased to 0.05 $\times 10^{7}$ cells $\mathrm{ml}^{-1}$ compared with $2.8 \times 10^{7}$ cells $\mathrm{ml}^{-1}$ for the total cellulolytic organisms. After $48 \mathrm{~h}, C$. longisporum was no longer detectable. $C$. herbivorans was identified in only one of the three cows after $24 \mathrm{~h}$ and was not detected at $72 \mathrm{~h}$. In a second study, when $C$. longisporum $\left(50 \mathrm{ml} ; 10^{7}\right.$ cells $\left.\mathrm{ml}^{-1}\right)$ was infused into the terminal ileum of seven pigs, it was not recovered when fecal samples were evaluated at 24, 48, or $72 \mathrm{~h}$ after infusion. These studies emphasize the competition that must be overcome to successfully introduce organisms into an intestinal ecosystem. Furthermore, these studies suggest that $C$. longisporum is a transient organism in the bovine rumen; however, $C$. herbivorans is part of the normal intestinal flora of some pigs, although the role that it plays in fiber degradation in these pigs is unclear.
\end{abstract}

Recently, two anaerobic cellulolytic clostridia have been isolated from gastrointestinal environments. One, Clostridium longisporum, was isolated from the rumen of a bison and a steer (16). Another, which we propose to name Clostridium herbivorans (20), was isolated from the pig intestinal tract (18). Both the ruminal and pig intestinal strains hydrolyze plant cell wall fractions as well as or better than the well-characterized ruminal cellulolytic organisms Fibrobacter succinogenes, Ruminococcus albus, and Ruminococcus flavefaciens $(16,18)$.

C. longisporum is found periodically in the bovine rumen (6, $14,16)$, and it is not established that $C$. herbivorans is part of the normal flora in pigs (18). Both of these cellulolytic clostridia have unique characteristics which make it possible to detect them in a mixed population of organisms. C. longisporum has a distinct orange pigment, making it easy to identify on cellobiose or cellulose roll tubes. $C$. herbivorans, in cellulose roll tubes, produces large zones of clearing when on the agar surface or sharp distinct zones of clearing with a colony when embedded in the agar (20), reactions which are distinguishable from those of the cellulolytic organisms $F$. succinogenes, $R$. albus, $R$. flavefaciens, and Butyrivibrio sp.

Successful introduction into and retention of ruminal bacteria in the rumen have occurred $(5,8)$. Transfer of mimosinemetabolizing bacteria from goats to cattle has had significant implications (8).

Because $C$. longisporum and $C$. herbivorans are intestinal organisms and have active cell wall-hydrolyzing abilities, efforts were made to introduce the pig cellulolytic organism into the rumen and the ruminal cellulolytic organism into other rumens and the pig intestinal tract. In each case, procedures to give the introduced organisms a numerical advantage were used. For the ruminant studies, for the culture to be in a better position

\footnotetext{
4148.

"Corresponding author. Phone: (402) 762-4207. Fax: (402) 762-

$\dagger$ Present address: Kansas State University, Southwest Research and Extension Center, Garden City, KS 67846.
}

to assume control of the fermentation, the rumens were evacuated to eliminate competitive organisms and refilled with buffer only and a large inoculum of the respective culture. For the pig studies, organisms were infused through a fistula entering the terminal ileum, thus bypassing the acidic environment of the stomach. An additional objective was to determine whether $C$. longisporum was responsible for donating its cellulase genes to one of the noncellulolytic clostridia in the pig large intestine, with the result being isolation of $C$. herbivorans.

\section{MATERIALS AND METHODS}

Animals. Three 6-year-old cows (approximately $550 \mathrm{~kg}$ each) fitted with ruminal fistulas were fed a chopped alfalfa diet and mineral supplement to which they had ad libitum access. Ruminal contents from the three cows were removed as thoroughly as possible with a cup. Twenty liters of McDougall's buffer (11) (equilibrated with $\mathrm{CO}_{2}$ for $2 \mathrm{~h}$ and preheated to $39^{\circ} \mathrm{C}$ ) and a 6-liter culture of $C$ longisporum B6405 (ATCC 49440) grown on cellobiose for $16 \mathrm{~h}$ were added to each rumen and mixed by hand. A 100-ml sample was withdrawn, blended for 1 min under $\mathrm{CO}_{2}$, and diluted in anaerobic buffer (13) for enumeration and tentative identification of cellulolytic organisms $(0 \mathrm{~h})$. After sampling, cows were allowed ad libitum access to food and water, which they readily consumed. Removal of the ruminal contents had no adverse affects on the animals. Rumens were again sampled at 5,24 , and $48 \mathrm{~h}$ to evaluate cellulolytic populations. Three weeks later, the same procedure was repeated with a culture of the pig intestinal cellulolytic organism C. herbivorans 54408 (ATCC 49925), and the rumens were sampled at 0,24 , and $72 \mathrm{~h}$.

Eight pigs, four large white crossbred ( $80 \mathrm{~kg}$ each) and four Meishan (imported from China; $70 \mathrm{~kg}$ each) were fed a $40 \%$ ground alfalfa and corn-soy diet. Each pig was fitted with a Mann-Ballman fistula in the terminal ileum, approximately $20 \mathrm{~cm}$ from the cecum (25) (Fig. 1). The $\mathrm{pH}$ of the intestinal contents at this location is near neutrality. Therefore, the infused organisms can enter the large intestine without being exposed to oxygen or the acidic environment of the stomach. The organisms may not survive when added directly to the diet. Ten days after the pigs had regained their preoperative appetite, fecal samples were collected from each pig on 3 consecutive days, and cellulolytic bacteria were enumerated and tentatively identified. These results served as the baseline control. C. longisporum OC4 grown on cellobiose for $16 \mathrm{~h}$ was infused by syringe ( 50 $\mathrm{ml} ; 10^{7}$ viable cells $\mathrm{ml}^{-1}$ ) into the terminal ileum of each pig. Fecal samples were collected at 24,48 , and $72 \mathrm{~h}$ after infusion, and cellulolytic bacteria were enumerated and tentatively identified.

In vitro enrichments of $\boldsymbol{C}$. herbivorans. Eight fecal enrichment cultures were established to determine whether the isolation of $C$. herbivorans was in any way dependent upon $C$. longisporum as hypothesized previously (18). Fecal samples 


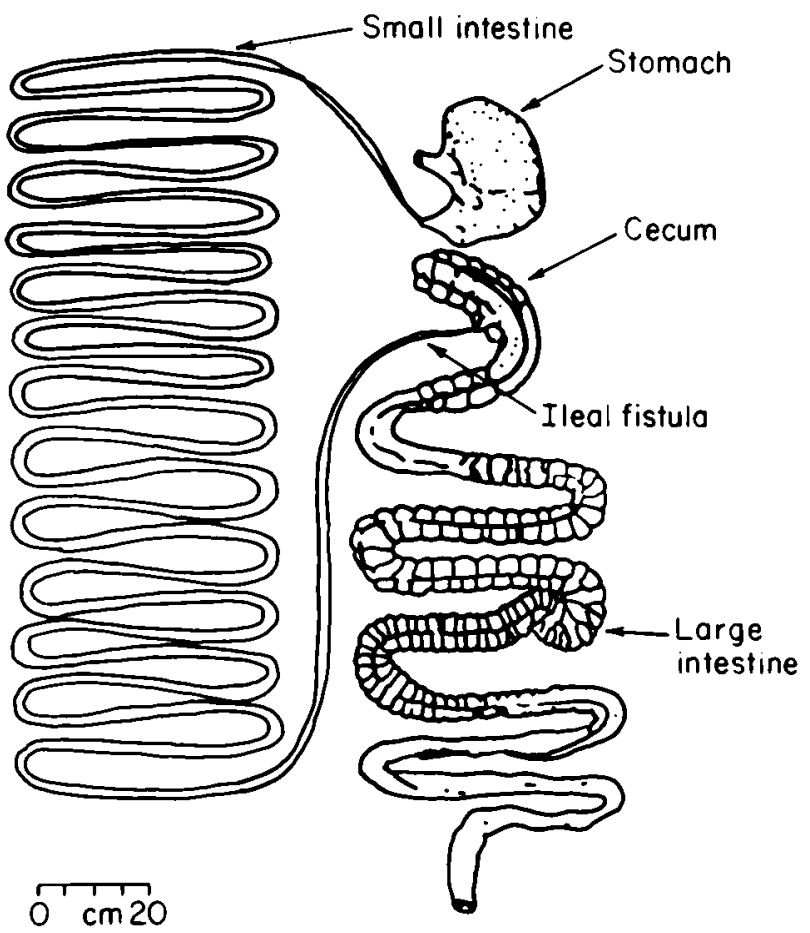

FIG. 1. Diagram of the pig gastrointestinal tract indicating the placement of the Mann-Ballman fistula in the terminal ileum.

were collected from two large white crossbred pigs (70 $\mathrm{kg}$ each) and two Meishan pigs ( $60 \mathrm{~kg}$ each), different from the animals above. These four pigs were also fed a $40 \%$ ground alfalfa and corn-soy diet. Enrichment media contained $0.5 \mathrm{~g}$ of alfalfa cell walls (19), $26 \mathrm{ml}$ of McDougall's buffer (11), and $2 \mathrm{~g}$ (wet weight) of fecal sample, and half of the cultures received a $2-\mathrm{ml}$ culture of $C$. longisporum OC4 $\left(10^{7}\right.$ viable cells $\left.\mathrm{ml}^{-1}\right)$. The other half of the cultures (four controls) received an additional $2 \mathrm{ml}$ of buffer. Enrichment cultures were sampled by syringe at 0,48 , and $96 \mathrm{~h}, 10$-fold dilutions were made, cellulose roll tubes were prepared, and cellulolytic organisms were enumerated and identified tentatively.

Bacteria, enumeration, and media. Two ruminal strains of $C$. longisporum, B6405 (bison) and OC4 (steer), were used in this study (16). One pig intestinal strain of $C$. herbivorans, 54408, was used (20). Large-volume cultures of these organisms were grown in 20-liter carboys with a 23 -gauge needle inserted through each rubber stopper, once growth was initiated, to vent gas produced.

The composition of the medium for mass culture of the clostridia was (per liter): clarified ruminal fluid, $150 \mathrm{ml}$; Trypticase (BBL Microbiology Systems, Cockeysville, Md.), $2 \mathrm{~g}$; cellobiose, $3.5 \mathrm{~g}$; yeast extract, $0.5 \mathrm{~g}$; mineral S2 (13), 50 $\mathrm{ml}$; resazurin, $0.001 \mathrm{~g} ; \mathrm{Na}_{2} \mathrm{CO}_{3}, 4 \mathrm{~g}$; and cysteine-hydrochloride, $0.5 \mathrm{~g}$. This and the other media were prepared under $\mathrm{CO}_{2}$ gas phase by the Hungate anaerobic culturing method as described by Bryant (3).

Roll tubes with cellulose or cellobiose as a substrate were used to enumerate cellulolytic organisms. These media were similar to that listed above, except that in cellulose roll tubes, cellulose (Whatman no. 1 filter paper ball milled with flint pebbles for $18 \mathrm{~h} ; 2 \mathrm{~g} /$ liter) replaced the cellobiose, clarified preincubated ruminal fluid (4) $(150 \mathrm{ml} /$ liter $)$ replaced the clarified ruminal fluid, and purified agar (BBL; $7.0 \mathrm{~g} /$ liter) was added. Cellulolytic organisms were enumerated at 3, 7, and 14 days as zones of clearing appeared in the roll tubes. Cellobiose roll tubes contained $2 \mathrm{~g}$ of cellobiose per liter, and the other components were identical to those in the cellulose roll tubes. Orange-pigmented colonies of $C$. longisporum were counted after 3 and 7 days. Recoveries of $C$. longisporum were similar for cellobiose and cellulose roll tubes. The numbers represent the mean of four replicate tubes per sampling. Isolates were picked to maintenance agar slant medium (18). Cellulolytic cultures were identified tentatively by methods described previously $(17,18)$. However, most cellulolytic organisms were readily identified by colony or lack of colony formation, zone of cellulose clearing, and observation of cellular morphology by phase-contrast microscopy.

\section{RESULTS}

Rumen studies. The survival of $C$. longisporum B6405 and the total number of cellulolytic bacteria found in buffer-ruminal fluid from three cows, after the rumens were evacuated, are
TABLE 1. Total number of cellulolytic bacteria and survival of C. longisporum B6405 in the rumen after ruminal contents were removed and replaced with buffer and a culture of B6405

\begin{tabular}{ccc}
\hline \multirow{2}{*}{$\begin{array}{c}\text { Time after B6405 } \\
\text { added (h) }\end{array}$} & \multicolumn{2}{c}{ No. of cellulolytic bacteria $\left(10^{7} / \mathrm{ml}\right)^{a}$} \\
\cline { 2 - 3 } & B6405 $^{b}$ & Total $^{c}$ \\
\hline 0 & 1.15 & 1.93 \\
5 & 0.55 & 0.88 \\
24 & 0.05 & 2.8 \\
48 & $\mathrm{ND}^{d}$ & 8.7 \\
SE & 0.06 & 0.5 \\
\hline
\end{tabular}

${ }^{a}$ Mean from three cows, four replicate tubes per cow; pooled error variance given.

${ }^{b}$ Counted on cellobiose roll tubes as orange colonies.

${ }^{c}$ Counted as zones of clearing on cellulose roll tubes, which include clearings produced by $\mathrm{B} 6405$.

${ }^{d} \mathrm{ND}$, none detected from a $10^{-3}$ dilution.

shown in Table 1. Immediately after the buffer and B6405 culture were added $(0 \mathrm{~h}), 1.15 \times 10^{7}$ cells of B6405 ml ${ }^{-1}$ were viable. The total population of cellulolytic organisms (including B6405) was $1.93 \times 10^{7}$ cells $\mathrm{ml}^{-1}$, which indicated that a minority of other cellulolytic organisms besides B6405 was present as expected. After $5 \mathrm{~h}$, the number of B6405 and total cellulolytic organisms decreased by greater than $50 \%$, although B6405 was still the predominant cellulolytic organism. Part of this decrease in number was a result of the larger fluid volume in the rumens after $5 \mathrm{~h}$. By $24 \mathrm{~h}$, only $1 \%$ of the B6405 organisms present at $5 \mathrm{~h}$ were viable, in contrast to a threefold increase in the total number of cellulolytic organisms. After 48 $\mathrm{h}$, no B6405 organisms were detected in a $10^{-3}$ dilution of ruminal fluid, while the total number of cellulolytic organisms increased another threefold.

The pig intestinal cellulolytic isolate C. herbivorans 54408 was introduced into the rumens at an average concentration of $2.33 \times 10^{7}$ cells ml ${ }^{-1}(0 \mathrm{~h}$; data not shown $)$. After $24 \mathrm{~h}$, strain 54408 was not detected in the ruminal fluid of two of the three cows. The concentration in the ruminal fluid of the third cow was $0.94 \times 10^{5}$ cells $\mathrm{ml}^{-1}$. Strain 54408 was not identified in any of the cows at $72 \mathrm{~h}$ after introduction.

Pig studies. Seven of the eight pigs prepared with fistulas were infused with the ruminal cellulolytic culture $C$. longisporum OC4. The numbers of fecal cellulolytic bacteria before and after infusion are shown in Table 2. C. longisporum OC4 was not recovered at any sampling time $(24,48$, or $72 \mathrm{~h})$ after being

TABLE 2. Total number of cellulolytic bacteria and C. herbivorans cells from seven pig fecal samples before and at 24,48 , and $72 \mathrm{~h}$ after $C$. longisporum OC4 infusion into the terminal ileum

\begin{tabular}{lcc}
\hline \multirow{2}{*}{ Sampling time } & \multicolumn{2}{c}{$\begin{array}{c}\text { No. of cellulolytic bacteria } \\
\left(10^{7} / \mathrm{g}[\mathrm{wet} \mathrm{wt}]\right)^{a}\end{array}$} \\
\cline { 2 - 3 } & C. herbivorans & Total \\
\hline Before infusion & $0.5^{b}$ & 1.8 \\
After infusion & & \\
$24 \mathrm{~h}$ & $0.8^{b}$ & 5.2 \\
$48 \mathrm{~h}$ & $0.7^{b}$ & 8.4 \\
$72 \mathrm{~h}$ & $0.8^{b}$ & 5.2 \\
$\mathrm{SE}$ & 0.1 & 1.3 \\
\hline
\end{tabular}

${ }^{a}$ Means before infusion represent a total of 21 samples; means after infusion represent 7 samples, except as indicated. C. longisporum was not recovered in any of the samples.

${ }^{b}$ Results from one pig; C. herbivorans was not observed in six other pigs. 
TABLE 3. Total number of cellulolytic bacteria and $C$. herbivorans cells from four pig fecal enrichments with or without additions of C. longisporum $\mathrm{OC} 4$ at the indicated incubation times ${ }^{a}$

\begin{tabular}{cccr}
\hline \multirow{2}{*}{$\begin{array}{c}\text { Incubation } \\
\text { time (h) }\end{array}$} & $\begin{array}{c}\text { Strain OC4 } \\
\text { addition }\end{array}$ & \multicolumn{2}{c}{$\begin{array}{c}\text { No. of cellulolytic bacteria } \\
\left(10^{7} / \mathrm{ml}\right)\end{array}$} \\
\cline { 3 - 4 } & & ${\text { C. } \text { herbivorans }^{b}}^{b}$ & Total $^{c}$ \\
\hline 0 & + & 0.4 & 3.2 \\
& - & 0.7 & 3.9 \\
& + & 27.5 & 30.4 \\
96 & - & 1.2 & 32.3 \\
& + & 0.5 & 24.1 \\
& - & 1.0 & 26.7 \\
SE & & & 3.1 \\
\hline
\end{tabular}

${ }^{a}$ Enrichment medium contained $0.5 \mathrm{~g}$ of alfalfa cell walls, buffer, $2 \mathrm{~g}$ of fecal sample, and $2 \mathrm{ml}$ of culture strain OC4 $\left(10^{7}\right.$ cells $\left.\mathrm{ml}^{-1}\right)$ where indicated.

${ }^{b}$ Results are from three of four pigs; this organism was not detected in the fourth pig.

${ }^{c}$ Includes C. longisporum, which was observed at $0 \mathrm{~h}$ but not at 48 or $96 \mathrm{~h}$.

infused. From one of seven pigs, $C$. herbivorans isolates were found consistently before and after infusion of OC4. Isolation of $C$. herbivorans before infusion ruled out the possibility that C. longisporum was influencing the presence of $C$. herbivorans, which was hypothesized from a previous study (18). From the earlier study (18), it was speculated that the cellulase enzyme complex may be transferred from $C$. longisporum to $C$. herbivorans.

To further evaluate the isolation of $C$. herbivorans from pig intestinal contents, with or without exposure to $C$. longisporum, fecal enrichments were established with inocula from four pigs ( $2 \mathrm{~g}$ of fecal sample plus or minus $2 \mathrm{ml}$ of culture of OC4) with alfalfa cell walls as a substrate. From three of the four enrichments (from two Meishan and one crossbred pigs), $C$. herbivorans was isolated at 0,48 , and $96 \mathrm{~h}$ with or without $C$. longisporum additions (Table 3 ). This confirmed that $C$. herbivorans is part of the normal flora in these pigs and is not dependent upon $C$. longisporum to transfer the cellulase complex. In these enrichments, $C$. herbivorans was the predominant cellulolytic organism at $48 \mathrm{~h}$ (Table 3 ). C. longisporum was recovered at $0 \mathrm{~h}$ but not at 48 or $96 \mathrm{~h}$. This suggests that this ruminal cellulolytic organism has little competitive ability in swine fecal cellulolytic enrichments.

\section{DISCUSSION}

The ruminal cellulolytic organism $C$. longisporum is present periodically in ruminal fluid at $10^{7}$ cells $\mathrm{ml}^{-1}(6,14,16)$, which suggests some compatibility with the rumen. Work in the present study indicates that a large inoculum of the culture into the rumen, in which it is the predominant cellulolytic organism, does not ensure that it will be competitive and survive. Without knowing more about the physiology of this organism and the environment of those rumens where it is found, we can only speculate as to why it does not survive. Conditions such as protozoal-bacterial predation, bacteriocins, bacteriophages, and other lytic factors could be responsible for a lack of survival $(2,7,9,22)$; however, volatile fatty acid toxicity $(21,23)$ is not likely a problem because its origin is the rumen. This is the first study that we are aware of in which nearly all of the ruminal contents are removed with the objective to establish an organism which was originally isolated from that ecosystem. We do not feel that evacuation of the ruminal contents removed a critical growth factor for $C$. longisporum to survive. The medium in which it was cultured had excess nutrients, and the animals ate immediately after the rumens were evacuated. The lack of success here emphasizes the problems to be overcome to successfully introduce organisms into the rumen.

C. longisporum is a cellulolytic organism; thus, adhesion to fiber particles is thought to be essential for survival in the rumen. Attachment is one area that might be evaluated further. Mittendorf and Thomson (12) have cloned an endo$(1 \rightarrow 4)$ - $\beta$-glucanase gene, CelA, from $C$. longisporum and found that it lacked the duplicate 24-amino-acid segments present in most Clostridium thermocellum and Clostridium cellulolyticum cellulases. Since these repeats are thought to be required for the binding of the cellulases to a protein of the cellulosome, it is speculated that $C$. longisporum does not have such a cellulosome structure. This may affect its ability to survive in the continuous-flow environment of the rumen because the cellulosome is one model proposed by which cellulases bind to cellulose substrates (10).

$C$. herbivorans survived in the rumen of one cow for $24 \mathrm{~h}$. One might assume that a pig intestinal isolate would not survive in the rumen. However, it should be kept in mind that the large intestine has many similarities to the rumen (24). Phylogenetic and phenotypic characteristics of $C$. herbivorans are very similar to those of the ruminal cellulolytic organism Clostridium polysaccharolyticum (20). Likewise, the cellulolytic organisms Fibrobacter intestinalis (pig intestine) and F. succinogenes (bovine rumen) are closely related (1), and $F$. intestinalis is present in the rumen in low numbers (15). Similarly, ruminal and intestinal isolates of $R$. flavefaciens are nearly identical phenotypically (17).

From the results of an earlier study (18) on the isolation of $C$. herbivorans, it was uncertain whether the ruminal cellulolytic organism $C$. longisporum influenced its recovery. On the basis of the data in the present study (Table 3), C. longisporum clearly does not influence the presence of $C$. herbivorans. It is concluded that $C$. herbivorans is part of the normal intestinal flora of some pigs because it was isolated from four pigs that had no exposure to $C$. longisporum. Two of the pigs from which C. herbivorans was isolated were Meishan (imported from China), which suggests a widespread ecological existence of this organism. The predominance of this organism in the pig fecal enrichment cultures at $48 \mathrm{~h}$ (Table 3 ), its number in the pig intestinal tract $\left(10^{7}\right.$ cells $\left.\mathrm{g}^{-1}\right)$ from one pig in this study and two pigs from a previous study (18), and its ability to degrade plant cell walls equally or better than the ruminal cellulolytic organisms (18) suggest that $C$. herbivorans may be one of the most active fiber-degrading organisms in some pigs.

In summary, neither the ruminal cellulolytic organism $C$. longisporum nor the swine intestinal cellulolytic organism $C$. herbivorans survived for more than $24 \mathrm{~h}$ in the rumen even though they were introduced at levels that exceeded all other cellulolytic bacteria. These results point out the strong competitive interactions that occur between the microbes and host animal which must be overcome before an organism can survive in the gastrointestinal tract. It is concluded that $C$. longisporum is likely a transient organism in the rumen. It is also concluded that $C$. herbivorans is part of the normal flora in some pigs and it may be widespread ecologically; however, we are uncertain about the role it plays in fiber degradation and why it is isolated only from select pigs.

\section{ACKNOWLEDGMENTS}

The technical assistance of Phil Anderson, Sandy Cummins, Keith Corwin, and Bruce Larsen and typing by Jan Watts are appreciated. 


\section{REFERENCES}

1. Amann, R. I., L. Chuzhao, K. Rebekah, L. Montgomery, and D. A. Stahl. 1992. Diversity among Fibrobacter isolates: towards a phylogenetic classification. Syst. Appl. Microbiol. 15:23-31.

2. Attwood, G. T., R. A. Lockington, G. P. Xue, and J. D. Brooker. 1988. Use of a unique gene sequence as a probe to enumerate a strain of Bacteroides ruminicola introduced into the rumen. Appl. Environ. Microbiol. 54:534539.

3. Bryant, M. P. 1972. Commentary on the Hungate technique for culture of anaerobic bacteria. Am. J. Clin. Nutr. 25:1324-1328.

4. Dehority, B. A., and J. A. Grubb. 1976. Basal medium for the selective enumeration of rumen bacteria utilizing specific energy sources. Appl. Environ. Microbiol. 32:703-710.

5. Flint, H. J., J. Bisset, and J. Webb. 1989. Use of antibiotic resistance mutations to track strains of obligately anaerobic bacteria introduced into the rumen of sheep. J. Appl. Bacteriol. 67:177-183.

6. Hungate, R. E. 1957. Microorganisms in the rumen of cattle fed a constant ration. Can. J. Microbiol. 3:289-311.

7. Jarvis, B. D. W. 1968. Lysis of viable rumen bacteria in bovine rumen fluid. Appl. Microbiol. 16:714-723.

8. Jones, R. J., and R. G. McGarrity. 1986. Successful transfer of DHP degrading bacteria from Hawaiian goats to Australian ruminants to overcome the toxicity of Leucaena. Aust. Vet. J. 63:259-262.

9. Klieve, A. V., and T. Bauchop. 1988. Morphological diversity of ruminal bacteriophages from sheep and cattle. Appl. Environ. Microbiol. 54:16371641.

10. Lamed, R., E. Setter, and E. A. Bayer. 1983. Characterization of a cellulosebinding, cellulase-containing complex in Clostridium thermocellum. J. Bacteriol. 156:828-836.

11. McDougall, E. I. 1948. Studies on ruminant saliva. I. The composition and output of sheep's saliva. Biochem. J. 42:99-105.

12. Mittendorf, V., and J. A. Thomson. 1993. Cloning of an endo-(1-4)- $\beta$-glucanase gene, celA, from the rumen bacterium Clostridium sp. (' $C$. longisporum') and characterization of its product, CelA, in Escherichia coli. J. Gen.
Microbiol. 139:3233-3242.

13. Salanitro, J. P., I. G. Fairchilds, and Y. D. Zgornicki. 1974. Isolation, culture characteristics, and identification of anaerobic bacteria from the chicken cecum. Appl. Microbiol. 27:678-687.

14. Sinha, R. N., and B. Ranganathan. 1983. Cellulolytic bacteria in buffalo rumen. J. Appl. Bacteriol. 54:1-6.

15. Stahl, D. A., B. Flesher, H. R. Mansfield, and L. Montgomery. 1988. Use of phylogenetically based hybridization probes for studies of ruminal microbial ecology. Appl. Environ. Microbiol. 54:1079-1084.

16. Varel, V. H. 1989. Reisolation and characterization of Clostridium longisporum, a ruminal sporeforming cellulolytic anaerobe. Arch. Microbiol. 152: 209-214.

17. Varel, V. H., S. J. Fryda, and I. M. Robinson. 1984. Cellulolytic bacteria from pig large intestine. Appl. Environ. Microbiol. 47:219-221.

18. Varel, V. H., and W. G. Pond. 1992. Characteristics of a new cellulolytic Clostridium sp. isolate from pig intestinal tract. Appl. Environ. Microbiol. 58:1645-1649.

19. Varel, V. H., A. J. Richardson, and C. S. Stewart. 1989. Degradation of barley straw, ryegrass, and alfalfa cell walls by Clostridium longisporum and Ruminococcus albus. Appl. Environ. Microbiol. 55:3080-3084.

20. Varel, V. H., R. S. Tanner, and C. R. Woese. Submitted for publication.

21. Wallace, R. J., M. L. Falconer, and P. K. Bharghava. 1989. Toxicity of volatile fatty acids at rumen $\mathrm{pH}$ prevents enrichment of Escherichia coli by sorbitol in rumen contents. Curr. Microbiol. 19:277-281.

22. Wallace, R. J., and N. D. Walker. 1993. Isolation and attempted introduction of sugar alcohol-utilizing bacteria in the sheep rumen. J. Appl. Bacteriol. 74:353-359.

23. Wolin, M. J. 1969. Volatile fatty acids and the inhibition of Escherichia coli growth by rumen fluid. Appl. Microbiol. 17:83-87.

24. Wolin, M. J. 1981. Fermentation in the rumen and human large intestine. Science 213:1463-1468.

25. Yen, J. T. 1991. Surgical techniques, p. 649-661. In E. Miller, D. Ullrey, and A. Lewis (ed.), Swine nutrition. Butterworth Publ., Stoneham, Mass. 